\title{
Cutaneous Melanoma Pathologic TNM Finding v6
}

National Cancer Institute

\section{Source}

National Cancer Institute. Cutaneous Melanoma Pathologic TNM Finding v6. NCI

Thesaurus. Code C48838.

A pathologic finding about one or more characteristics of cutaneous melanoma,

following the rules of the TNM AJCC v6 classification system. TNM pathologic findings are based on clinical findings supplemented by histopathologic examination of one or more tissue specimens acquired during surgery. 